\title{
Serum Amylase Increased
}

National Cancer Institute

\section{Source}

National Cancer Institute. Serum Amylase Increased. NCI Thesaurus. Code C78608.

A laboratory test indicating increased levels of amylase in the serum. 